Jurnal Akuntansi Manajerial

ISSN (E): 2502-6704

Vol. 5, No. 2 Juli - Desember 2020: 1-11
Dipublikasikan oleh Fakultas Ekonomi dan Bisnis

Universitas 17Agustus 1945 Jakarta

http://journal.uta45jakarta.ac.id/index.php/JAM

\title{
Pengaruh Pertumbuhan Perusahaan Dan Kepemilikan Manajerial Terhadap Keputusan Investasi Dengan Kualitas Laba Sebagai Variabel Intervening
}

\author{
Siti Barokah ${ }^{1)}$,Robiur Rahmat Putra., SE., M.Si., Ak. ${ }^{2)}$ \\ ${ }^{1}$ Mahasiswa Akuntansi, Universitas 17 Agustus 1945 Jakarta \\ Email: sitibarokah732@gmail.com \\ ${ }^{2}$ Dosen Fakultas Ekonomi dan Bisnis, Universitas 17 Agustus 1945 Jakarta \\ Email: robiur.rahmat@uta45jakarta.ac.id
}

\begin{abstract}
Abstrak :
Penelitian ini bertujuan untuk mengetahui pengaruh pertumbuhan perusahaan dan kepemilikan manajerial terhadap keputusan investasi dengan kualitas laba sebagai variabel intervening. pertumbuhan perusahaan dan kepemilikan manajerial sebagai variabel independen sedangkan keputusan investasi sebagai variabel dependen serta kualitas laba sebagai variabel intervening. Populasi dalam penelitian ini adalah Seluruh perusahaan BUMN yang terdaftar di Bursa Efek Indonesia pada tahun 2015-2019 yang terdiri dari 20 perusahaan. Setelah dilakukan pengumpulan data serta pengambilan sampel dengan menggunakan metode purposive sampling melalui kriteria-kriteria yang telah ditetapkan maka sampel yang digunakan dalam penelitian ini adalah berjumlah 6 perusahaan BUMN. Pengujian hipotesis ini menggunakan STATA sebagai alat uji. Metode analisis data diuji dengan uji statistik deskriptif, korelasi, uji moltikolinearitas, uji heteroskedastisitas, uji autokorelasi serta uji normalitas. Uji hipotesis dilihat dari analisis hasil analisis SEM. Hasil penelitian membuktikan bahwa pertumbuhan perusahaan berpengaruh positif signifikan terhadap keputusan investasi. Kepemilikan manajerial tidak berpengaruh terhadap keputusan investasi. Pertumbuhan perusahaan tidak berpengaruh terhadap kualitas laba. Kepemilikan manajerial tidak berpengaruh terhadap kualitas laba. kualitas laba berpengaruh signifikan terhadap tingkat keputusan investasi. Tidak ada pengaruh signifikan antara hubungan pertumbuhan perusahaan terhadap keputusan investasi melalui kualitas laba. Tidak ada pengaruh signifikan antara hubungan kepemilikan manajerial terhadap keputusan investasi melalui kualitas laba. Kata kunci : Keputusan Investasi, Pertumbuhan Perusahaan, Kepemilikan Manajerial, Kualitas Laba.
\end{abstract}

\begin{abstract}
:
This study aims to determine the effect of company growth and managerial ownership on investment decisions with earnings quality as an intervening variable. company growth and managerial ownership as independent variables, while investment decisions as the dependent variable and earnings quality as aniintervening variable. The population in this study were all state-owned companies listed on the Indonesia Stock Exchange in 2015-2019, which consisted of 20 companies. After data collection and sampling using purposive sampling method through predetermined criteria, the samples used in this study were 6 state-owned companies. Testing this hypothesis using STATA as a test tool. The data analysis method was tested by descriptive statistical test, correlation, moltikolinearity test, heteroscedasticity test, autocorrelation test and normality test. Hypothesis testing is seen from the analysis of SEM analysis results.The research results prove that company growth has a significant positive effect on investment decisions. Managerial ownership has no effect on investment decisions. Company growth has no effect on earnings quality. Managerial ownership has no effect on earnings quality. Earning quality has a significant effect on the level of investment decisions. There is no significant influence between the relationship between company growth and investment decisions through earnings quality. There is no significant influence between managerial ownership on investment decisions through earnings quality.
\end{abstract}

Keywords: Investment Decisions, Company Growth, Managerial Ownership, Earnings Quality. 
Jurnal Akuntansi Manajerial

ISSN (E): 2502-6704

Vol. 5, No. 2 Juli - Desember 2020: 1-11
Dipublikasikan oleh Fakultas Ekonomi dan Bisnis

Universitas 17Agustus 1945 Jakarta

http://journal.uta45jakarta.ac.id/index.php/JAM

\section{PENDAHULUAN}

Keputusan investasi didefinisikan sebagai keputusan seorang individu untuk meletakkan sejumlah dananya pada jenis investasi tertentu. Penilaian keputusan investasi dapat dinilai dengan prosentase individu dalam menentukan besarnya dana yang diinvestasikan pada akun bank dan aset riil. Investasi pada akun bank adalah investasi yang dilakukan pada aktiva yang merupakan produk bank seperti, tabungan, giro dan deposito. Investasi pada aset tetap adalah investasi yang dilakukan pada aset yang bisa terlihat dan dapat diukur dengan jelas seperti, rumah, tanah, emas, dan sebagainya. Berikut perbandingan pertumbuhan perusahaan dengan Keputusan Investasi :

Tabel 1. Perbandingan pertumbuhan perusahaan dengan Keputusan Investasi

\begin{tabular}{|l|r|r|r|}
\hline Nama perusahaan & Tahun & Pertumbuhan perusahaan & Keputusan Investasi \\
\hline PT. Jasa Marga Tbk & 2019 & 0.209 & 0.173 \\
\cline { 2 - 4 } & 2018 & 0.041 & 0.039 \\
\cline { 2 - 4 } & 2017 & 0.480 & 0.324 \\
\cline { 2 - 4 } & 2016 & 0.457 & 0.314 \\
\cline { 2 - 4 } & 2015 & 0.153 & 0.132 \\
\hline \multirow{5}{*}{ Wijaya Karya Tbk } & 2019 & 0.049 & 0.046 \\
\cline { 2 - 4 } & 2018 & 0.297 & 0.229 \\
\cline { 2 - 4 } & 2017 & 0.457 & 0.314 \\
\cline { 2 - 4 } & 2016 & 0.600 & 0.375 \\
\cline { 2 - 4 } & 2015 & 0.232 & 0.188 \\
\hline PT. Bank Negara & 2019 & 0.046 & 0.044 \\
\cline { 2 - 4 } (Persero) Tbk & 2018 & 0.140 & 0.123 \\
\cline { 2 - 4 } & 2017 & 0.176 & 0.150 \\
\cline { 2 - 4 } & 2016 & 0.186 & 0.157 \\
\cline { 2 - 4 } & 2015 & 0.221 & 0.181 \\
\hline PT. Telekomunikasi & 2019 & 0.0728 & 0.068 \\
\cline { 2 - 4 } Indonesia & 2018 & 0.0388 & 0.037 \\
\cline { 2 - 4 } (Persero) Tbk & 2017 & 0.1050 & 0.095 \\
\cline { 2 - 4 } & 2016 & 0.0824 & 0.076 \\
\cline { 2 - 4 } & 2015 & 0.1716 & 0.147 \\
\hline
\end{tabular}

Dari tabel diatas, ada contoh 4 perusahaan BUMN periode 2015-2019. Tabel diatas menunjukkan pertumbuhan perusahaan dan keputusan nvestasi yang terus meningkat setiap tahunnya.Hal ni dikarenakan jika perusahaan mengalami kenaikan laba atau aset setiap tahunnya maka ada kemungkinan suatu perusahaan akan meningkatkan jumlah nvestasi nya pula. Pengeluaran nvestasi merupakan sinyal positif terhadap pertumbuhan perusahaan di masa yang akan datang, sehingga meningkatkan harga. Pengeluaran nvestasi yang dilakukan oleh perusahaan memberikan sinyal kepada nvestor dan kreditur bahwa perusahaan akan tumbuh di masa mendatang (Spence, 1973). Pernyataan tersebut didukung oleh Yusintha \& Suryandari (2010) yang berpendapat bahwa pertumbuhan perusahaan pada dasarnya menggambarkan bagaimana perusahaan menginvestasikan dana yang a miliki untuk kegiatan operasi dan nvestasi. Peningkatan jumlah aset, baik aset lancar maupun aset jangka panjang membutuhkan dana, dengan alternatif pendanaan nternal atau dengan pendanaan eksternal. Pertumbuhan perusahaan perusahaan mencerminkan pertumbuhan sumber daya berupa aset yang dimiliki perusahaan dan diukur dari perbedaan nilai total aset setiap tahun. Pertumbuhan perusahaan menunjukkan alokasi nvestasi aset yang dilakukan perusahaan.

Berdasarkan penjelasan diatas ditemukan beberapa hasil riset terdahulu yang menunjukkan hasil berbeda karena dipengaruhi oleh situasi, kondisi dan objek penelitian. Hal ini mendorong peneliti untuk melakukan penelitian kembali atas ketidakkonsistenan antar variabel tersebut. Perbedaan penelitian ini dengan penelitian sebelumnya adalah terletak pada variabel kualitas laba yang menginterneving 
Jurnal Akuntansi Manajerial

ISSN (E): 2502-6704

Vol. 5, No. 2 Juli - Desember 2020: 1-11
Dipublikasikan oleh Fakultas Ekonomi dan Bisnis

Universitas 17Agustus 1945 Jakarta

http://journal.uta45jakarta.ac.id/index.php/JAM

hubungan pertumbuhan perusahaan dan kepemilikan manajerial terhadap keputusan investasi dimana pada penelitian sebelumnya ketiga variabel tersebut belum banyak diteliti secara bersama-sama.

\section{LITERATUR REVIEW DAN HIPOTESIS Grand Theory (Signalling Theory)}

Menurut Brigham (2001) isyarat atau signal adalah suatu tindakan yang diambil perusahaan untuk memberi petunjuk bagi investor tentang bagaimana manajemen memandang prospek perusahaan. Sinyal ini berupa informasi mengenai apa yang sudah dilakukan oleh manajemen untuk merealisasikanikeinginan pemilik. Signalling theory menjelaskan mengapa perusahaan mempunyai dorongan untuk memberikan informasi laporan keuangan pada pihak eksternal. Dorongan perusahaan untuk memberikan informasi karena terdapat asimetri informasi antara perusahaan dan pihak luar karena perusahaan mengetahui lebih banyak mengenai perusahaan dan prospek yang akan datang daripada pihak luar (investor dan kreditor). Kurangya informasi bagi pihak luar mengenai perusahaan meyebabkan mereka melindungi diri mereka dengan memberikan harga yang rendah untuk perusahaan.

\section{Pertumbuhan Perusahaan terhadap Keputusan Investasi}

Pertumbuhan perusahaan yang tinggi memberikan lebih banyak pilihan yang riil untuk investasi dimasa yang akan datang dibandingkan dengan perusahaan yang memiliki pertumbuhan yang rendah. Jika pertumbuhan suatu perusahaan tinggi maka memerlukan tambahan pembiayaan pendanaan yang cukup tinggi untuk pembiayaan dimasa yang akan datang. Hasil penelitian Komalasari et al. (2015) menyatakan bahwa semakin tinggi nilai dari pertumbuhan perusahaan maka peluang investasi yang dihadapi oleh perusahaan ke depan juga semakin besar. Peneliti lainnya yang telah membuktikan pengaruh pertumbuhan perusahaan terhadap keputusan investasi adalah Irawati (2012). Dari pernyataan diatas dapat ditarik hipotesis pertama yaitu :

H1: Pertumbuhan perusahaan berpengaruh signifikan terhadap keputusan investasi.

\section{Kepemilikan Manajerial terhadap Keputusan Investasi}

Dalam penelitian yang dilakukan oleh Puput \& Adi permana (2015) menunjukkan bahwa corporate governance yang diukur dengan menggunakan tingkat kepemilikan manajerial berhubungan negatif dengan investasi dan tidak signifikan secara statistik. Hal ini menunjukkan bahwa kecenderungan yang terjadi bahwa ketika tingkat kepemilikan institusional cenderung meningkat, maka tingkat investasi yang dilakukan perusahaan semakin lebih prudent karena tingkat investasi yang mereka lakukan akan dimonitor oleh pemegang saham institusional. Penelitian dari Nasrum et al. (2015) menunjukkan bahwa bahwa struktur kepemilikan di mana ada kepemilikan manajerial dan kepemilikan institusional mempengaruhi perusahaan keputusan investasi. Peneliti lainnya yang telah membuktikan pengaruh kepemilikan manajerial terhadap keputusan investasi adalah lestari (2014) dan Komalasari (2015). Dari pernyataan diatas dapat ditarik hipotesis kedua yaitu

H2: Kepemilikan manajerial berpengaruh signifikan terhadap keputusan investasi.

\section{Pertumbuhan Perusahaan terhadap Kualitas Laba}

Menurut Irawati (2012) pertumbuhan laba berpengaruh negatif terhadap kualitas laba dicocokkan dengan kriteria distribusi bahwa rata-rata pertumbuhan laba masuk dalam kriteria sangat rendah. Artinya kemampuan perusahaan masih rendah dalam menaikkan laba perusahaan setiap periode. Namun perusahaan menahan labanya untuk kegiatan ekspansi yang berarti perusahaan tersebut tidakimelakukan manipulasi laba sehingga informasi laba perusahaan berkualitas. Pentingnya informasi laba bagi stakeholders menuntut laba yang dilaporkan tidak hanya tinggi dalam hal angka, namun juga berkualitas dalam penyajiannya. Laporan keuangan dikatakan tidak dapat diandalkan apabila menyajikan kualitas laba yang buruk, karena kualitas laba yang buruk tidak dapat memprediksikan kondisi keuangan perusahaan di masa depan. Peneliti lainnya yang telah membuktikan pengaruh pertumbuhan perusahaan 
Jurnal Akuntansi Manajerial ISSN (E): 2502-6704

Vol. 5, No. 2 Juli - Desember 2020: 1-11
Dipublikasikan oleh Fakultas Ekonomi dan Bisnis

Universitas 17Agustus 1945 Jakarta

http://journal.uta45jakarta.ac.id/index.php/JAM

terhadap kualitas laba adalah Sadiah \& Priyadi (2015). Dari pernyataan diatas dapat ditarik hipotesis ketiga yaitu

H3: Pertumbuhan perusahaan berpengaruh signifikan terhadap kualitas laba.

\section{Kepemilikan Manajerial terhadap Kualitas Laba}

Perusahaan dikatakan memiliki kualitas laba yang baik jika laba yang dilaporkan tersebut dapat digunakan oleh pengguna laporan keuangan untuk membuat keputusan yang terbaik (Warianto \& Rusiti, 2016). Perusahaan yang memiliki kualitas laba yang baik cenderung dapat mengelola dan mengalokasikan sumber daya dengan baik sehingga kondisi tersebut dapat meningkatkan efisiensi perusahaan (Al-dhamari \& Ismail, 2015). Penelitian yang dilakukan oleh Wirama (2014) menunjukkan hasil kepemilikan manajerial berpengaruh signifikan terhadap kualitas laba. Peneliti lainnya yang telah membuktikan pengaruh kepemilikan manajerial terhadap kualitas laba adalah Daromes (2016), Darabali \& Saitri (2016) dan Restuningdiah (2016). Dari pernyataan diatas dapat ditarik hipotesis keempat yaitu,

H4: Kepemilikan manajerial berpengaruh signifikan terhadap kualitas laba.

\section{Kualitas Laba terhadap Keputusan Investasi}

Bar-Gill \& Bebchuk (2005) menyatakan bahwa perusahaan yang memiliki kualitas laba yang buruk seringkali melakukan investasi yang tidak efisien karena perusahaan menyajikan kinerja keuangannya lebih tinggi dari yang seharusnya dengan tujuan untuk memperoleh pembiayaan yang lebih murah. Hasil penelitian tersebut sama dengan penelitian yang dilakukan oleh Puput \& Adi permana (2015) yang menyimpulkan bahwa pengaruh kualitas laporan keuangan terhadap tingkat investasi perusahaan yang mengalami over-investment. Dengan kata lain bahwa tingkat over-investment perusahaan dipengaruhi oleh faktor lain selain kualitas laporan keuangan. Dari pernyataan diatas dapat ditarik hipotesis kelima yaitu,

H5: kualitas laba berpengaruh signifikan terhadap keputusan investasi.

\section{Pertumbuhan Perusahaan terhadap Keputusan Investasi Melalui Kualitas Laba}

Irmayanti (2011) Pertumbuhan laba dimungkinkan ada pengaruh dengan kualitas laba perusahaan karena jika perusahaan yang memiliki kesempatan bertumbuh terhadap labanya berarti kinerja keuangan perusahaan tersebut baik dan dimungkinkan juga memiliki kesempatan bertumbuh terhadap kualitas labanya. Hal ini dikarenakan perusahaan dengan kinerja saham perusahaan yang baik cenderung berusaha memiliki kualitas laba yang baik karena fokus utamanyaiadalah bertumbuh dan berkembang untuk menarik minat investor. Maka pertumbuhan laba berpengaruh positif terhadap kualitas laba. Dari pernyataan diatas dapat ditarik hipotesis keenam yaitu,

H6: pertumbuhan perusahaan berpengaruh signifikan terhadap keputusan investasi melalui kualitas laba.

\section{Kepemilikan Manajerial terhadap Keputusan Investasi Melalui Kualitas Laba}

Subagya (2017) menyatakan bahwa Kualitas laba tidak memediasi kepemilikan managerial dan institusional pada nilai perusahaan. Komite audit yang baik akan meningkatkan nilai perusahaan dan akan semakin baik lagi bila kualitas labanya baik. Hal ini sangat rasional karena laba mencerminkan nilai perusahaan. Nilai perusahaan di tentukan laba yang diperoleh dari perusahaan dari waktu ke waktu. Kepemilikan manajerial dan institusional tidak dimediasi oleh kualitas laba. Kepemilikan sering tidak mempengaruhi kualitas laba. Banyak sedikitnya kepemilikan manajerial dan institusional tidak mempengaruhi nilai perusahaan. Keadaan walaupun kepemilikan manajerial dan instittusional baik tetapi kualitas labanya tidak baik maka nilai perusahaan tetap tidak baik. Hal ini merupakan keadaan yang rasional. Memperhatikan konsep di atas dan dukungan dari penelitian terdahulu lebih banyak menyatakan signifikan, maka dibentuk hipotesis kedua yaitu: kepemilikan manajerial berpengaruh signifikan terhadap keputusan investasi melalui kualitas laba. 
Jurnal Akuntansi Manajerial

ISSN (E): 2502-6704

Vol. 5, No. 2 Juli - Desember 2020: 1-11
Dipublikasikan oleh Fakultas Ekonomi dan Bisnis

Universitas 17Agustus 1945 Jakarta

http://journal.uta45jakarta.ac.id/index.php/JAM

\section{METODE PENELITIAN}

\section{Populasi dan Penentuan Sampel}

Populasi dalam penelitian ini adalah semua perusahaan BUMN yang terdaftar di Bursa Efek Indonesia periode 2014-2019 sebanyak 20. Pada penelitian ini dipilih perusahaan BUMN karena mempunyai peranan yang strategis dalam mendukung pembangunan dan pertumbuhan ekonomi nasional. Kriteriakriteria pengambilan sampel secara purposive sampling dalam penelitian ini sebagai berikut : (1) Perusahaan BUMN yang terdaftar di Bursa Efek Indonesia dari tahun 2014 sampai 2019, (2) Perusahaan BUMN yang melaporkan data keuangan dengan nilai mata uang rupiah, (3) Perusahaan BUMN yang tercatat tidak memiliki laba negatif selama periode 2014 - 2019, (4) Perusahaan BUMN yang berturutturut mengeluarkan laporan tahunannya per 31 Desember 2014 - 31 Desember 2019, (5) Perusahaan yang memuat informasi lengkap yang dibutuhkan dalam penelitian.

\section{Definisi Operasionalisasi Variabel dan Pengukuran Variabel}

\section{Variabel Dependen}

\section{Keputusan Investasi}

Keputusan investasi didefinisikan sebagai kombinasi antara aktiva yang dimiliki (assets in place) dengan pilihan investasi dimasa yang akan datang dengan net present value positif. IOS tidak dapat diobeservasi secara langsung, sehinggaidalam perhitungannya menggunakan proksi (Kallapur \& Trombley, 1999). Proksi IOS dalam penelitian ini adalah CPA/BVA atau Ratio Capital Expenditure to Book Value of Asset. Pengukuran keputusan investasi menggunakan rumus:

$C B A / B V A$

$=\frac{\text { Pertumbuhan aktiva }}{\text { Total aktiva tahun } \mathrm{X}}$

CPA/BVA = Ratio Capital Expendititure to Book Value of Asset

Pertumbuhan aktiva = Total aktiva Tahun $X-$ Total aktiva tahun $X-1$

\section{Variabel Independen}

\section{Pertumbuhan Perusahaan}

Pertumbuhan adalah dampak atas arus dana perusahaan dari perubahan operasional yang disebabkan oleh pertumbuhan atau penurunan volume usaha (Herfet, 1997). Pertumbuhan perusahaan sangat diharapkan oleh pihak internal maupun eksternal perusahaan, karena pertumbuhan yang baik memberi tanda bagi perkembangan perusahaan. Pengukuran pertumbuhan perusahaan menggunakan rumus :

Growth $=\frac{\text { Total asset tahun berjalan }- \text { Total asset tahun sebelumnya }}{\text { Total asset tahun sebelumnya } i}$

\section{Kepemilikan Manajerial}

Herawaty and Hoque (2007) mengemukakan bahwa kepemilikan manajerial merupakan saham perusahaan yang dimiliki oleh manajemen secara pribadi maupun dimiliki oleh anak cabang perusahaan bersangkutan besar pada keputusan-keputusan yang akan diambil oleh perusahaan kedepannya. Maka dengan kepemilikan manajerial yang besar di perusahaan, akan berdampak pada kekuasaan dalam perusahaan itu. pengukuran variabel kepemilikan menggunakan rumus :

Kepemilikan Manajerial $=\frac{\text { Jumlah saham yang dimiliki direktur dan komisaris }}{\text { jumlah saham }} \times 100 \%$ 
Jurnal Akuntansi Manajerial

ISSN (E): 2502-6704

Vol. 5, No. 2 Juli - Desember 2020: 1-11
Dipublikasikan oleh Fakultas Ekonomi dan Bisnis

Universitas 17Agustus 1945 Jakarta

http://journal.uta45jakarta.ac.id/index.php/JAM

\section{Variabel Intervening}

Kualitas laba adalah kemampuan laba dalam laporan keuangan untuk menjelaskan kondisi laba perusahaan yang sesungguhnya sekaligus digunakan dalam memprediksi laba masa depan (Bellovary et al. 2005). Adapun Pengukuran variabel kualitas laba menggunakan rumus :

$$
\text { Quality of Income }=\frac{\text { Arus kas operasi }}{\text { Laba bersih tahun berjalan }}
$$

\section{ANALISIS DAN PEMBAHASAN}

\section{Hasil Pemilihan Sampel}

Setelah dilakukan pengumpulan data serta pengambilan data serta pengambilan sampel dengan memakai purposive sampling melalui kriteria-kriteria yang telah ditetapkan. Maka sampel yang digunakan dalam riset ini adalah berjumlah 6 perusahaan BUMN dengan periode laporan keuangan 2015-2019 atau dapat dijelaskan bahwa subyek memiliki time series selama 5 tahun.

Tabel 2. Daftar Perusahaan Sampel

\begin{tabular}{|c|c|c|}
\hline No & Kode Perusahaan & Nama Perusahaan \\
\hline 1 & WIKA & Wijaya Karya Tbk \\
\hline 2 & BBNI & PT. Bank Negara Indonesia (Persero) Tbk \\
\hline 3 & PTBA & Bukit Asam Tbk \\
\hline 4 & JSMR & Jasa Marga Tbk \\
\hline 5 & TLKM & PT. Telekomunikasi Indonesia (Persero) Tbk \\
\hline 6 & BBRI & PT. Bank Rakyat Indonesia (Persero) Tbk \\
\hline
\end{tabular}

Sumber : www.idx.co.id, data telah diolah

\section{Statistik Deskriptif}

Tabel 3 menunjukkan statistic deskriptif masing-masing variabel penelitian yaitu pertumbuhan perusahaan, kepemilikan manajerial, kualitas laba dan keputusan investasi.

\begin{tabular}{|c|l|c|c|c|c|}
\hline Variabel & Obs & Mean & Std. Dev & Minimum & Maksimum \\
\hline Keputusan investasi & 30 & -0.1596667 & 0.547402 & -6.82 & 0.97 \\
\hline Pertumbuhan perusahaan & 30 & 0.181 & 0.1426679 & 0.04 & 0.6 \\
\hline Kepemilikan Manajerial & 30 & 0.001101 & 0.0001651 & 0.000012 & 0.00085 \\
\hline Kualitas laba & 30 & 1.188667 & 0.7833867 & -0.92 & 2.66 \\
\hline
\end{tabular}

\section{Tabel 3. Statistik Deskriptif}

Sumber : Hasil Olahan Data Dengan Stata, 2020

Tabel 3 menunjukkan variabel pertumbuhan perusahaan memiliki nilai minimum 0,04, nilai maksimum 0,6 dengan rata-rata dan standar deviasi masing-masing sebesar 0,181 dan 0,1426679. Kepemilikan manajerial memiliki nilai minimum 0,000012, nilai maksimum 0,00085 dengan rata-rata dan standar deviasi masing-masing sebesar 0,001101 dan 0,0001651. Kualitas laba memiliki nilai minimum -0,92, nilai maksimum 2,66 dengan rata-rata dan standar deviasi masing-masing sebesar 1,188667 dan 0,783867. Keputusan investasi memiliki nilai minimum -6,82, nilai maksimum 0,97 dengan rata-rata dan standar deviasi masing-masing sebesar -0,1596667 dan 0,547402. 
Jurnal Akuntansi Manajerial

ISSN (E): 2502-6704

Vol. 5, No. 2 Juli - Desember 2020: 1-11
Dipublikasikan oleh Fakultas Ekonomi dan Bisnis

Universitas 17Agustus 1945 Jakarta

http://journal.uta45jakarta.ac.id/index.php/JAM

\section{Uji Asumsi Klasik}

a) Uji normalitas. Dilihat dari nilai combined K-S lebih besar dari nilai signifikansi (5\%) Maka data berdistribusi normal yang berarti asumsi normalitas terpenuhi.

b) Uji multikoleritas. Nilai tolerance semua variabel bebas lebih besar dari 0,10 , demikian pula nilai VIF semuanya kurang dari 10. Dengan demikian dapat disimpulkan bahwa model regresi tidak mengindikasikan adanya multikolinieritas.

c) Uji autokolerasi. Nilai probability lebih besar dari tingkat signifikansi (5\%). Dengan demikian penelitian ini bebas masalah autokorelasi.

d) Uji heteroskedastisitas. Nilai prob > chi2 lebih besar dari tingkat signifikansi (5\%). Dengan demikian penelitian ini bebas masalah heteroskedastisitas.

\section{Uji Hipotesis}

\section{Hasil Pengaruh Langsung}

Setelah pengujian asumsi klasik diatas, maka dibawah ini akan diuraikan mengenai pengujian pengaruh pertumbuhan perusahaan, kepemilikan manajerial terhadap keputusan investasi dan kualitas laba sebagai variabel intervening. Berikut ini hasil pengolahan data :

Tabel 4. Structural Equation Modelling

\begin{tabular}{|c|c|c|c|c|c|c|}
\hline & Coef. & Err & $\mathrm{Z}$ & $\mathrm{p}>\mathrm{IzI}$ & \multicolumn{2}{|c|}{$95 \%$ Conf. Interval) } \\
\hline \multicolumn{7}{|l|}{ Structural kualitas laba } \\
\hline Pertumbuhan perusahaan & -0.478 & 1.016 & -0.47 & 0.638 & -2.470 & 1.512 \\
\hline Kepemilikan Manajerial & -582.0 & 866.0 & -0.67 & 0.502 & -2279. & 1115. \\
\hline \multicolumn{7}{|l|}{ Structural keputusan investasi } \\
\hline Kualitas laba & 0.00 & 0.0024 & 2.77 & 0.006 & 0.001 & 0.115 \\
\hline Pertumbuhan perusahaan & 0.60 & 11.65 & 44.61 & 0.000 & 0.581 & 0.634 \\
\hline Kepemilikan Manajerial & 20.52 & 0.0045 & 1.76 & 0.078 & -2.326 & 43.37 \\
\hline Kualitas laba & 0.576 & 0.14 & & & 0.3475 & 0.95563 \\
\hline Keputusan investasi & 0.000 & 0.000 & & & 0.0000 & 0.0001 \\
\hline
\end{tabular}

Sumber: Hasil olahan data dengan STATA, 2020

\section{Pembahasan Hipotesis Pengaruh Pertumbuhan Perusahaan Terhadap Keputusan Investasi}

Berdasarkan hasil tabel diatas variabel pertumbuhan perusahaan terhadap keputusan investasi menunjukkan nilai sebesar 0,000 dengan nilai koefisien 2,77. Hal ini menunjukkan bahwa variabel pertumbuhan perusahaan berpengaruh secara signifikan positif terhadap keputusan investasi. Hal tersebut ditunjukkan dengan nilai $(\mathrm{P}>|\mathrm{z}|)$ 0,000 lebih kecil dari tingkat signifikansi $(0,05)$. Dengan demikian hasil riset pertumbuhan perusahaan terhadap keputusan investasi selaras dengan penelitian Puput (2015) dan Irawati (2012).

Hal ini membuktikan bahwa hipotesis pertama (H1) diterima. Diterimanya hipotesis pertama disebabkan karena pertumbuhan perusahaan yang tinggi memberikan lebih banyak pilihan yang riil untuk investasi dimasa yang akan datang dibandingkan dengan perusahaan yang memiliki pertumbuhan yang rendah. Semakin besar peluang pertumbuhan perusahaan, maka tingkat investasi yang dilakukan oleh perusahaan juga semakin besar.

\section{Pembahasan Hipotesis Pengaruh Kepemilikan Manajerial Terhadap Keputusan Investasi}

Pengaruh langsung variabel kepemilikan manajerial terhadap keputusan investasi $(\mathrm{X} 2 \mathrm{Y})=0,078$. Hal ini menunjukkan bahwa variabel kepemilikan manajerial tidak berpengaruh terhadap keputusan investasi. Hal tersebut ditunjukkan dengan nilai ( $\mathrm{P}>|\mathrm{z}|)$ 0,078 lebih besar dari tingkat signifikansi $(0,05)$. Dengan demikian hasil riset kepemilikan manajerial terhadap keputusan investasi selaras dengan penelitian Sely (2019) dan Komalasari et al. (2015) 
Jurnal Akuntansi Manajerial ISSN (E): 2502-6704

Vol. 5, No. 2 Juli - Desember 2020: 1-11
Dipublikasikan oleh Fakultas Ekonomi dan Bisnis

Universitas 17Agustus 1945 Jakarta

http://journal.uta45jakarta.ac.id/index.php/JAM

Hal ini membuktikan bahwa hipotesis kedua (H2) ditolak. Ditolaknya hipotesis kedua disebabkan pada perusahaan BUMN untuk kepemilikan manajerial nilainya sangat kecil karena mayoritas saham pada perusahaan BUMN dimiliki oleh pemerintah. Komisaris dan direktur yang memiliki saham tidak mempunyai banyak kemampuan untuk menentukan keputusan investasi perusahaan nya. Dan menurut penelitian Komalasari et al. (2015) hasil yang tidak signifikan ini menunjukkan bahwa tidak semua aktivitas investasi termonitor oleh pemegang saham mengingat rapat dengan pemegang saham jumlahnya sangat terbatas.

\section{Pembahasan Hipotesis Pengaruh Pertumbuhan Perusahaan Terhadap Kualitas Laba}

Pengaruh langsung variabel pertumbuhan perusahaan terhadap kualitas laba $(\mathrm{X} 1 \mathrm{Z})=0,638$. Hal ini menunjukkan bahwa variable pertumbuhan perusahaan tidak berpengaruh secara signifikan terhadap kualitas laba. Hal tersebut ditunjukkan dengan nilai $(\mathrm{P}>|\mathrm{z}|)$ 0,677 lebih besar dari tingkat signifikansi $(0,05)$. Dengan demikian hasil ini sejalan hasilnya dengan penelitian Irawati (2012), Oktarya \& Dkk (2012), Laoli \& Herawaty (2019) dan Dira \& Astik (2014).

Hal ini membuktikan bahwa hipotesis ketiga (H3) ditolak. Ditolaknya hipotesis ketiga disebabkan karena pertumbuhan suatu perusahaan tidak dapat mengindikasikan kualitas laba dari perusahaan tersebut. Sehingga bisa saja perusahaan yang tumbuh memiliki kualitas laba yang baik ataupun buruk.

\section{Pembahasan Hipotesis Pengaruh Kepemilikan Manajerial Terhadap Kualitas Laba}

Pengaruh langsung variabel kepemilikan manajerial terhadap kualitas laba $(\mathrm{X} 1 \mathrm{Z})=0,502$. Hal ini menunjukkan bahwa variabel kepemilikan manajerial tidak berpengaruh terhadap kualitas laba. Hal tersebut ditunjukkan dengan nilai $(\mathrm{P}>|\mathrm{z}|)$ 0,502 lebih besar dari tingkat signifikansi $(0,05)$. Sehingga hipotesis keempat (H4) dinyatakan ditolak. Dengan demikian hasil riset ini sejalan dengan penelitian yangidilakukan oleh Subagya (2017), Fathussalmi et al. (2019) dan Murniati et al. (2018).

Kepemilikan saham oleh pihak manajerial tidak dapat mempengaruhi kualitas laba suatu perusahaan karena perusahaan masih memiliki komisaris independen dan auditor independen untuk menjaga kualitas laporan keuangan perusahaan tersebut. Hal ini lah yang menyebabkan kepemilikan manajerial tidak berpengaruh terhadap kualitas laba.

\section{Pembahasan Hipotesis Pengaruh Kualitas laba Terhadap Keputusan Investasi}

Pengaruh langsung variabel kualitas laba terhadap keputusan investasi $(\mathrm{Z} \mathrm{Y})=0,006$. Hal ini menunjukkan bahwa variabel kualitas laba berpengaruh secara signifikan terhadap keputusan investasi. Hal tersebut ditunjukkan dengan nilai $(\mathrm{P}>|\mathrm{z}|)$ 0,006 lebih kecil dari tingkat signifikansi $(0,05)$. Dengan demikian hasil ini hipotesis kelima diterima. Hasil ini sejalan dengan penelitian yang dilakukan oleh Subagya (2017).

Diterimanya hipotesis kelima disebabkan karena jika perusahaan memiliki laba yang berkualitas maka investor akan cenderung berminat untuk berinvestasi. Laba yang berkualitas akan menghasilkan keputusan investasi yang berkualitas pula.

\section{Pengaruh Tidak Langsung}

Tabel 5. Indirect Effect

\begin{tabular}{|c|r|r|l|l|r|r|}
\hline & \multicolumn{1}{|l|}{ Coef. } & \multicolumn{1}{l|}{ Std. Err } & z & p> IzI & 95\% Conf. Interval) \\
\hline Structural keputusan investasi & \multicolumn{7}{|l|}{} \\
\hline Pertumbuhan perusahaan & -0.0032 & 0.0069 & 0.46 & 0.642 & 0.0168 & 0.0104 \\
\hline Kepemilikan Manajerial & -3.93 & 6.021 & 0.65 & 0.514 & -15.73 & 7.86 \\
\hline
\end{tabular}

Sumber: Hasil olahan data dengan STATA, 2020 


\section{Pengaruh Pertumbuhan Perusahaan Terhadap Keputusan Investasi Melalui Kualitas Laba Sebagai Variabel Mediasi}

Pengaruh tidak langsung variabel pertumbuhan perusahaan terhadap keputusan investasi (X1 Y)=0,642 dengan nilai koefisien -0.46. Nilai $(\mathrm{P}>|\mathrm{z}|)$ 0,642 lebih besar dari nilai signifikansi $(0,05)$ dengan koefisien bernilai negatif. Hal ini menunjukkan bahwa variabel pertumbuhan perusahaan tidak berpengaruh terhadap keputusan investasi dengan kualitas laba sebagai variabel mediasi. Sehingga hasil pengujian hipotesis keenam (H6) dinyatakan ditolak. Hasil ini disebabkan karena tidak adanya pengaruh signfikan pertumbuhan perusahaan terhadap kualitas laba dan kualitas laba tidak berpengaruh signifikan terhadap keputusan investasi. Kolerasi pengaruh tidak langsung pertumbuhan perusahaan terhadap keputusan investasi adalah negatif dikarenakan variabel intervening keputusan investasi berpengaruh negatif.

\section{Pengaruh Kepemilikan Manajerial Terhadap Keputusan Investasi Melalui Kualitas Laba Sebagai Variabel Mediasi}

Pengaruh tidak langsung variabel kepemilikan manajerial terhadap keputusan investasi $(\mathrm{X} 2 \mathrm{Y})=0,514$ dengan nilai koefisien $-0,65$. Nilai $(\mathrm{P}>|\mathrm{z}|)$ 0,514 lebih besar dari nilai signifikansi $(0,05)$ dengan koefisien bernilai negatif. Hal ini menunjukkan bahwa variabel kepemilikan manajerial tidak berpengaruh signifikan terhadap keputusan investasi dengan kualitas laba sebagai variabel mediasi. Sehingga hasil pengujian hipotesis ketujuh (H7) dinyatakan ditolak. Hasil ini disebabkan karena tidak adanya pengaruh signfikan kepemilikan manajerial terhadap kualitas laba dan kualitas laba tidak berpengaruh signifikan terhadap keputusan investasi Kolerasi pengaruh tidak langsung kepemilikan manajerial terhadap keputusan investasi adalah negatif dikarenakan variabel intervening keputusan investasi berpengaruh negative.

\section{KESIMPULAN}

Kesimpulan dari penelitian ini adalah :

1. Pertumbuhan perusahaan berpengaruh secara signifikan terhadap keputusan investasi disebabkan karena perusahaan yang memiliki pertumbuhan tinggi akan diminati sahamnya oleh para investor. Semakin tinggi atau besar laba perusahaan maka perusahaan akan cenderung menginvestasikan nya.

2. Kepemilikan manajerial tidak berpengaruh terhadap keputusan investasi. Disebabkan karena pada perusahaan BUMN untuk kepemilikan manajerial nilainya sangat kecil karena mayoritas saham pada perusahaan BUMN dimiliki oleh pemerintah.

3. Pertumbuhan perusahaan tidak berpengaruh terhadap kualitas laba. karena kemampuan perusahaan masih rendah dalam menaikkan laba perusahaan setiap periode. Namun perusahaan menahan labanya untuk kegiatan ekspansi yang berarti perusahaan tersebut tidak melakukan manipulasi laba sehingga informasi laba perusahaan berkualitas.

4. Kepemilikan manajerial tidak berpengaruh secara signifikan terhadap kualitas laba. Hal ini disebabkan karena perusahaan memiliki komisaris independen dan auditor independen untuk menjaga kualitas laporan keuangan.

5. Kualitas laba berpengaruh secara signifikan terhadap keputusan investasi. Hasil ini disebabkan karena jika perusahaan memiliki laba yang berkualitas maka investor akan cenderung berminat untuk berinvestasi. Laba yang berkualitas akan menghasilkan keputusan investasi yang berkualitas pula.

6. Pertumbuhan perusahaan tidak berpengaruh signifikan terhadap keputusan investasi melalui kualitas laba. Kolerasi pengaruh tidak langsung pertumbuhan perusahaan terhadap keputusan investasi adalah positif dikarenakan variabel intervening keputusan investasi berpengaruh positif.

7. Kepemilikan manajerial tidak berpengaruh signifikan terhadap keputusan investasi melalui kualitas laba. Kolerasi pengaruh tidak langsung kepemilikan manajerial terhadap keputusan investasi adalah negatif dikarenakan variabel intervening keputusan investasi berpengaruh negatif. 
Jurnal Akuntansi Manajerial

ISSN (E): 2502-6704

Vol. 5, No. 2 Juli - Desember 2020: 1-11
Dipublikasikan oleh Fakultas Ekonomi dan Bisnis

Universitas 17Agustus 1945 Jakarta

http://journal.uta45jakarta.ac.id/index.php/JAM

\section{Keterbatasan Penelitian}

Keterbatasan penelitian yang mempengaruhi hasil penelitian ini adalah sampel yang digunakan di penelitian ini sangatlah kecil karena dalam penelitian ini menggunakan sampel perusahaan BUMN yang kepemilikan saham dipegang sebagian besar oleh pemerintah sehingga variabel kepemilikan manajerial kurang maksimal dalam pengukurannya.

\section{Saran}

Saran yang dapat diaplikasikan bagi peneliti selanjutnya adalah dapat menambahkan variabel independen lain yang kemungkinan dapat memengaruhi keputusan investasi serta agar dilakukan penelitian dengan rentang waktu yang lebih panjang dan dilakukan penelitian pada perusahaan sektor lainnya agar semua uji dapat dilakukan dan didapatkan hasil yang lebih bagus.

\section{DAFTAR PUSTAKA}

Al-dhamari, R., \& Ku Ismail, K. N. I. (2015). Cash Holdings, Political Connections, And Earnings Quality. International Journal of Managerial Finance, 4(1). https://doi.org/10.1108/ijmf-02-2014-0016

Bar-Gill, O., \& Bebchuk, L. A. (2005). Misreporting Corporate Performance. SSRN Electronic Journal. https://doi.org/10.2139/ssrn.354141

Bellovary, J.L., Giacomino, D.E. and Akers, M. D. (2005). Earnings Quality: Its Time To Measure And Report. The CPA Journal, 75(11), 32-37.

Brigham, E. F. ; J. F. H. (2001). Manajemen Keuangan.

Darabali, P. M., \& Saitri, P. W. (2016). Analisis Faktor-Faktor Yang Mempengaruhi Kualitas Laba Pada Perusahaan Manufaktur Di Bursa Efek Indonesia Tahun 2010-2013. Jurnal Riset Akuntansi, 2(1), 1-6.

Dira, P. K., \& Astika, I. B. P. (2014). Pengaruh struktur modal, likuiditas, pertumbuhan laba, dan ukuran perusahaan pada kualitas laba. E-Jurnal Akuntansi Universitas Udayana.

Fathussalmi, F., Darmayanti, Y. D., \& Fauziati, P. F. (2019). Pengaruh Investment Opportunity Set dan Corporate Governance Terhadap Kualitas Laba (Studi Empiris Pada Perusahaan Manufaktur yang Listing di BEI tahun 2011-2015). Reviu Akuntansi Dan Bisnis Indonesia, 3(2), 124-138. https://doi.org/10.18196/rab.030240

Herawaty, M. and Hoque, Z. (2007). Disclosure In The Annual Reports Of Australian Government Departments: A Research Note. Journal of Accounting \& Organizational Change, Vol. 3(https://doi.org/10.1108/18325910710756159), 147-168.

Herfet, E. A. (1997). Teknik Analisis Keuangan, Penerjemah Herman Wibowo., Edisi Kedelapan, Jakarta: Erlangga.

Irawati, D. E. (2012). Pengaruh Struktur Modal, Pertumbuhan Laba, Ukuran Perusahaan Dan Likuiditas Terhadap Kualitas Laba. Accounting Analysis Journal, 1(2), 1-6. https://doi.org/10.15294/aaj.v1i2.572

Irmayanti, H. (2011). Manajemen Operasional Perspektif Integratif, Malang: Uin Malik Press.

Kallapur, S. \& Trombley, M. A. (1999). The Association Between Investment Opportunity Set Proxies and Relized Growth. Journal of Business Finance \& Accounting, 26(3), 505-519.

Komalasari, Puput \& Adi permana, I. gede. (2015). Kualitas Laba dan Pengaruhnya Terhadap Keputusan Investasi. Jurnal Ekonomi Dan Bisnis. Universitas Airlangga, 6(2).

Laoli, A. N., \& Herawaty, V. (2019). Pengaruh Profitabilitas, Growth, Leverage, Operating Cycle Dan Prudence Terhadap Kualitas Laba Dengan Firm Size Sebagai Variabel Moderasi. Prosiding Seminar 
Jurnal Akuntansi Manajerial

ISSN (E): 2502-6704

Vol. 5, No. 2 Juli - Desember 2020: 1-11
Dipublikasikan oleh Fakultas Ekonomi dan Bisnis Universitas 17Agustus 1945 Jakarta

http://journal.uta45jakarta.ac.id/index.php/JAM

Nasional Cendekiawan, 2(2). https://doi.org/10.25105/semnas.v0i0.5828

Murniati, T., Sastri, I. I. D. A. . M., \& Rupa, I. W. (2018). Faktor - faktor yang Mempengaruhi Kualitas Laba Pada Perusahaan Manufaktur yang Terdaftar Di BEI tahun 2012 - 2016. Kumpulan Riset Akuntansi, 9(5).

Nasrum, M., Akal, A. T. U., \& lan, D. (2015). The Influence of Ownership Structure and Corporate Governance to Investment Decision Companies Listed on Indonesia Stock Exchange. Kuwait Chapter of Arabian Journal of Business and Management Review, 4(7), 15-19. https://doi.org/10.12816/0018978

Oktarya, \& Dkk. (2012). Pengaruh Pertumbuhan Laba , Investment Opportunity Set, Leverage dan Ukuran Perusahaan Terhadap Kualitas Laba pada Perusahaan Manufaktur yang Terdaftar di BEI. Accounting Analysis Journal, 10(1), 1-15.

Puput Tri Komalasari, I. G. A. P. (2015). Kualitas Laba Dan Pengaruhnya Terhadap Keputusan Investasi. Jurnal Ekonomi Dan Bisnis, 7(3).

Restuningdiah, N. (2016). The Mediating Effect of Financial Reporting Quality on the Relation Between Corporate Governance Mechanism and the Stock Price of Consumer Goods Industry Listed in Indonesia Stock Exchange. South East Asia Journal of Contemporary Business, Economics and Law, 11(1), 16-21. Retrieved from http://seajbel.com/wp-content/uploads/2017/01/ACC-221.pdf

Sadiah, H., \& Priyadi, M. P. (2015). Pengaruh Leverage, Likuiditas, Size, Pertumbuhan Laba dan IOS Terhadap Kualitas laba. Jurnal Ilmu Dan Riset Akuntansi, 4(5), 1-20. Retrieved from https://anzdoc.com/pengaruh-leverage-likuiditas-size-pertumbuhan-laba-dan-ios-t.html

Sely Megawati Wahyudi, W. C. (2019). The Effect of Good Corporate Governance on Investment Decisions and Profitability and Its Impact on Corporate Value. E-Jurnal Akuntansi, 2(2).

Spence, M. (1973). Job Market Signaling. The Quarterly Journal of Economics. https://doi.org/10.2307/1882010

Subagya, Y. H. (2017). Keterkaitan Kepemilikan Manajerial, Institusional, Dan Komite Audit Pada Nilai Perusahaan Di Mediasi Oleh Kualitas Laba. Jurnal Perilaku Dan Strategi Bisnis, 5(2), 117-132. https://doi.org/10.26486/jpsb.v5i2.353

Suwandi, D., \& Fransiskus, E. (2016). Peran Kemampuan Manajerial Sebagai Mekanisme Peningkatan Kualitas Laba Dan Nilai Perusahaan. Jurnal Akuntansi Dan Keuangan Indonesia, 3(1), 5-15. https://doi.org/10.21002/jaki.2016.10

vlestari, noviana \& khafid, muhammad \& I. (2014). Pengaruh Good Corporate Governance dan Nilai Terhadap Perusahaan Laba Dengan Kualitas Variabel Sebagai Variabel Intervening. Accounting Analysis Journal, 3(1), 34-43.

Warianto, P., \& Rusiti, C. (2016). Pengaruh Ukuran Perusahaan, Struktur Modal, Likuiditas Dan Investment Opportunity Set (Ios) Terhadap Kualitas Laba Pada Perusahaan Manufaktur Yang Terdaftar Di Bei. MODUS, 4(1). https://doi.org/10.24002/modus.v26i1.575

Wirama, P. T. dan D. G. (2014). Pengaruh Konservatisme akuntansi, Good Corporate Governance terhadap Kualitas laba. E-Jurnal Akuntansi Universitas Udayana, 1(3).

Yusintha, P., \& Suryandari, E. (2010). Analisis Faktor-Faktor Yang Mempengaruhi Struktur Modal. Jurnal Akuntansi Dan Investasi, 5(2), 17-42. 
Jurnal Akuntansi Manajerial

ISSN (E): 2502-6704

Vol. 5, No. 2 Juli - Desember 2020: 1-11
Dipublikasikan oleh Fakultas Ekonomi dan Bisnis Universitas 17Agustus 1945 Jakarta http://journal.uta45jakarta.ac.id/index.php/JAM 